\title{
Accurate use of neutrophil/lymphocyte ratio from the perspective of laboratory experts
}

\author{
This article was published in the following Dove Press journal: \\ Vascular Health and Risk Management \\ 20 December 2013 \\ Number of times this article has been viewed
}

\section{Erdim Sertoglu' \\ Metin Uyanik ${ }^{2}$ \\ 'Biochemistry Laboratory, Ankara Mevki Military Hospital, Anittepe \\ Dispensary, Ankara, Turkey; \\ ${ }^{2}$ Department of Medical Biochemistry, \\ Gulhane School of Medicine, \\ Ankara, Turkey}

\section{Dear editor}

I read with great interest the recent published article "Neutrophil/lymphocyte ratio in patients with atrial septal aneurysm" by Demir and Demir. ${ }^{1}$ In this study, researchers compared the neutrophil/lymphocyte ratio (NLR) between patients with atrial septal aneurysm (ASA) and controls. It was reported that patients with ASA have higher NLR compared with controls. ${ }^{1}$ There are some points that we would like to address from this study.

Firstly, a white blood cell (WBC) count of more than 12,000 cells per $\mu \mathrm{L}$, or less than 4,000 cells per $\mu \mathrm{L}$, was mentioned as one of the exclusion criteria. ${ }^{1}$ However, the authors did not state why these values were used as the limits for inclusion. Whether a WBC count of more than 12,000 cells per $\mu \mathrm{L}$ is accepted as an indicator of inflammation or infection is unclear, and there is no mention of the literature that this value is based on, or which device (brand/model) was used for the WBC count. The WBC reference ranges may vary depending on many factors such as the population studied, the individual laboratory, and the instruments (eg, types of collection tubes) or measurement methods used (eg, waiting period prior to analysis). ${ }^{2,3}$

Secondly, despite comparing groups based on neutrophil and lymphocyte counts, there was no exclusion criteria specified for these parameters. According to Horne et al, ${ }^{4}$ and as stated in the study, ${ }^{1}$ high neutrophil, monocyte, and NLR counts, as well as low lymphocyte counts, are independently related to increased cardiovascular events. However, in this study, Table 2 shows an increased total lymphocyte count (TLC) in controls $\left(2,911 \pm 837\right.$ cells per $\left.\mathrm{mm}^{3}\right)$ draws attention rather than the low TLC of patients $\left(1,862 \pm 625\right.$ cells per $\left.\mathrm{mm}^{3}\right) .{ }^{1} \mathrm{~A}$ TLC significantly higher than 2,900 lymphocytes in a $\mu \mathrm{L}$ of blood is generally considered to be an indicator of lymphocytosis in adults. ${ }^{3}$ If you accept 2,900 cells per $\mathrm{mm}^{3}$ as the upper limit of the TLC, the differential diagnosis of lymphocytosis should be given to the controls included in the study. However, in several other sources 4,000 cells per $\mathrm{mm}^{3}$ is regarded as the upper limit of the TLC. ${ }^{5,6}$ Additionally, although the TLC obtained from the patient group was relatively lower than in the control group, all results were within the reference values. ${ }^{3}$ Therefore, it would not be correct to declare that the patient group had a low TLC. On the basis of this information, evaluation of the percentage of lymphocytes and neutrophils may also be important in patient groups with borderline TLC values. Automated blood counting instruments should provide percentage values for each type of WBC count.
Ankara Mevki Military Hospital, Anittepe Dispensary, 06580 Cankaya, Ankara, Turkey

Tel $+903 / 24562888$

$\mathrm{Fax}+903123043300$

Email erdimsertoglu@gmail.com 
Thirdly, the measurement of NLR was suggested as an indicator of increased risk of arrhythmia, based on the association found between ASA and NLR in the study, however the physiopathological causes supporting this conclusion were not thoroughly discussed. ${ }^{1}$ NLR has been used frequently to predict outcomes in patients with cancer and coronary artery disease. ${ }^{7,8}$ Systemic inflammation is thought to be a risk factor for cardiovascular disease, and NLR, which integrates the detrimental effects of neutrophilia (an indicator of inflammation) and lymphopenia (an indicator of physiological stress), has emerged as a useful prognostic marker. ${ }^{8}$ Possible causes affecting neutrophil/lymphocyte counts and the confounding factors which have a considerable effect on the clinical availability of NLR should be discussed in more detail in this study population.

Finally, NLR itself alone without other inflammatory markers may not accurately provide information about the prognosis of the patients. There are studies evaluating soluble P- and E-selectin, interleukin-6, and high-sensitivity C-reactive protein (hs-CRP) as indices of prothrombogenic and proinflammatory activity in a similar group of patients. ${ }^{9,10}$ While assessing the predictive values of parameters like NLR (derived from the ratios), and comparing them for validity and accuracy, proven markers will provide more reliable results every time.

In conclusion, the types of collection tubes, waiting period prior to analysis, instrumental parameters and reference ranges for each parameter must be specified as they are easily affected by analytical and preanalytical variables in studies based on laboratory results. ${ }^{11}$

\section{Disclosure}

The authors report no conflicts of interest in this correspondence.

\section{References}

1. Demir M, Demir C. Neutrophil/lymphocyte ratio in patients with atrial septal aneurysm. Vasc Health Risk Manag. 2013;9:365-368.

2. Buttarello M, Plebani M. Automated blood cell counts: state of the art. Am J Clin Pathol. 2008;130(1):104-116.

3. $\mathrm{CBC}$ with differential, Blood. [webpage on the Internet]. USA: Mayo Medical Laboratories; [cited October 27, 2013]. Available from: http://www.mayomedicallaboratories.com/test-catalog/ Clinical+and+Interpretive/9109. Accessed June 3, 2013.

4. Horne BD, Anderson JL, John JM, et al; Intermountain Heart Collaborative Study Group. Which white blood cell subtypes predict increased cardiovascular risk? J Am Coll Cardiol. 2005;45:1638-1643.

5. bpac $^{\mathrm{nz}}$. Complete Blood Count in Primary Care; New Zealand: bpac ${ }^{\mathrm{nz}}$; 2008. Available from: http://www.bpac.org.nz/resources/campaign/ cbc/bpac_cbc_in_primary_care.pdf. Accessed November 7, 2013.

6. Thomas D Coates. Approach to the patient with lymphocytosis or lymphocytopenia [updated February 18, 2013]. Available from: http://www. uptodate.com/contents/approach-to-the-patient-with-lymphocytosis-orlymphocytopenia. Accessed December 11, 2013.

7. Halazun KJ, Hardy MA, Rana AA, et al. Negative impact of neutrophil-lymphocyte ratio on outcome after liver transplantation for hepatocellular carcinoma. Ann Surg. 2009;250(1):141-151.

8. Gibson PH, Cuthbertson BH, Croal BL, et al. Usefulness of neutrophil/ lymphocyte ratio as predictor of new-onset atrial fibrillation after coronary artery bypass grafting. Am J Cardiol. 2010;105(2):186-191.

9. Na JO, Shin SY, Lim HE, et al. Impaired transport function of the left atrium and left atrial appendage in cryptogenic stroke patients with atrial septal aneurysm and without patent foramen ovale. Eur J Echocardiogr. 2011;12(2):140-147.

10. Conway DS, Buggins P, Hughes E, Lip GY. Relation of interleukin-6, C-reactive protein, and the prothrombotic state to transesophageal echocardiographic findings in atrial fibrillation. Am J Cardiol. 2004;93(11):1368-1373.

11. Koepke JA, Landay AL. Precision and accuracy of absolute lymphocyte counts. Clin Immunol Immunopathol. 1989;52(1):19-27.
Vascular Health and Risk Management

\section{Publish your work in this journal}

Vascular Health and Risk Management is an international, peerreviewed journal of therapeutics and risk management, focusing on concise rapid reporting of clinical studies on the processes involved in the maintenance of vascular health; the monitoring, prevention and treatment of vascular disease and its sequelae; and the involvement of

\section{Dovepress}

metabolic disorders, particularly diabetes. This journal is indexed on PubMed Central and MedLine. The manuscript management system is completely online and includes a very quick and fair peer-review system, which is all easy to use. Visit http://www.dovepress.com/ testimonials.php to read real quotes from published authors. 